\title{
STOP TUBERKULOSIS MELALUI PENDEKATAN MODEL INFORMATION MOTIVATION AND BEHAVIORAL SKILLS (IMB)
}

\section{STOPPING TUBERCULOSIS BY INFORMATION MOTIVATION BEHAVIORAL SKILLS (IMB) MODELLING APPROACH}

\author{
${ }^{1)}$ Rita Benya Adriani, ${ }^{2}$ Dyah Dwi Astuti, ${ }^{3)}$ Tri Widyastuti Handayani \\ 1,2,3) Jurusan Keperawatan \\ Poltekkes Kemenkes Surakarta \\ Jalan Letjend Sutoyo, Mojosongo, Surakarta, 57127, Indonesia \\ **Email: astutidyah83@gmail.com
}

\begin{abstract}
ABSTRAK
Tuberkulosis merupakan masalah kesehatan global terutama yang terjadi di negara berkembang dan dapat menyebabkan kematian. Penatalaksanaan tuberkulosis di Indonesia mengalami kendala antara lain kegagalan pengobatan dan stigma negatif. Kegiatan pengabdian masyarakat ini bertujuan untuk melakukan deteksi dini, serta meningkatkan pengetahuan, sikap, dan ketrampilan dalam pencegahan penularan tuberkulosis dengan melibatkan kader kesehatan, tokoh masyarakat, dan puskesmas pembina wilayah. Kegiatan pengabdian masyarakat dilakukan dengan pemberian pendidikan kesehatan melalui pendekatan model information, motivation, and behavioral skills berdasarkan hasil evidence based practice. Deteksi dini menunjukkan bahwa terdapat 2 orang $(4,7 \%)$ yang mengalami gejala utama tuberkulosis yaitu batuk berdahak 2 minggu atau lebih. Gejala tambahan yang paling sering dialami berupa penurunan berat badan dijumpai sebanyak 8 orang (18,6\%). Mayoritas masyarakat mempunyai information, motivation, and behavioral skills yang positif setelah kegiatan pengabdian masyarakat. Kegiatan pengabdian masyarakat dapat meningkatkan pengetahuan, sikap, dan ketrampilan dalam pencegahan tuberkulosis. Rekomendasi kegiatan ini adalah untuk melaksanakan kegiatan pengabdian masyarakat secara berkelanjutan dengan melibatkan stakeholder terkait dan pendekatan model information, motivation, and behavioral skills.
\end{abstract}

Kata kunci: Model Information Motivation and Behavioral Skills; Komunitas; dan Tuberkulosis

\begin{abstract}
Tuberculosis is a global health problem that mainly occurs in developing countries that can cause deaths. The treatment of tuberculosis di Indonesia undergoes some issues such as medication failures and the stigma of it. The community service activity is aimed to get an early detection, broaden knowledge, improve attitude and skills in preventing the transmission of tuberculosis by involving health cares, community leaders, and public health. The community service activity was performed by a method of providing health education by applying the information-motivation-behavioral skills modeling approach based on the result of evidence-based practice. Early detection showed two people (4.7\%) who experienced the main symptom of tuberculosis, coughing with phlegm for two weeks or more. The additional symptom most frequently experienced by the patients was weight loss, which in this case, was experienced by eight patients (18.6\%). Most of the people have had positive informationmotivation-behavioral skills after the community service. Community service activities can increase knowledge, attitudes, and skills in tuberculosis prevention. It is recommended that the intervention can be continuously carried out by involving the related stake-holders and by applying the informationmotivation-behavioral skills modeling approach.
\end{abstract}

Keywords: Community; Information Motivation and Behavioral Skills Model; Tuberculosis

Submitted : 20 November 2019 Revision : 24 Juli 2020 Accepted : 2 September 2020 


\section{PENDAHULUAN}

Tuberkulosis (TBC) merupakan masalah kesehatan global terutama yang terjadi di negara berkembang. TBC menyebabkan kematian sekitar 1,4 juta orang pada tahun 2015 di dunia (Watermeyer \& Penn, 2019). Indonesia menduduki peringkat kedua tertinggi kasus TBC di dunia. World Health Organization (WHO) pada tahun 2014 mencatat kasus TBC di Indonesia mencapai 1.000.000 kasus dan jumlah kematian akibat TBC diperkirakan 110.000 kasus setiap tahunnya. Angka penemuan kasus TBC yang ternotifikasi (Case Notification Rate/CNR) di Provinsi Jawa Tengah tercatat 210,8 kasus (Dinas Kesehatan Provinsi Jawa Tengah, 2019).

Penatalaksanaan TBC di Indonesia mengalami beberapa kendala antara lain hambatan dalam melakukan deteksi dini di masyarakat, kegagalan pengobatan, dan stigma terhadap penyakit TBC. Keterlambatan dalam penegakan diagnosis dan pengobatan TBC berhubungan dengan keparahan, serta keluaran pengobatan yang buruk (Yin et al., 2018). Kendala tersebut dapat disebabkan oleh rendahnya pengetahuan masyarakat tentang penyakit TBC (Pinto et al., 2018). Upaya peningkatan pengetahuan masyarakat tentang penyakit TBC dapat dilakukan dengan pemberian pendidikan kesehatan, sehingga terbentuk perilaku masyarakat yang positif (Anandari, Masfiah, \& Wijayanti, 2018).

Pelaksanaan program pendidikan kesehatan bermanfaat dalam meningkatkan kesadaran masyarakat dan memperkuat koordinasi antara masyarakat dengan petugas kesehatan terutama di pelayanan kesehatan primer seperti puskesmas (Okeyo \& Dowse, 2018). Peningkatan

\section{METODE}

Kegiatan pengabdian masyarakat ini dilakukan berdasarkan evidence based practice melalui telaah jurnal penelitian. Pertanyaan pada kegiatan pengabdian koordinasi tersebut berdampak pada keberhasilan program kesehatan seperti stop TBC, serta peningkatan kemampuan masyarakat dalam mengambil keputusan untuk melakukan pengobatan yang tepat (Pinto et al., 2018). Pengetahuan masyarakat tentang penyakit TBC akan berpengaruh terhadap respon perilaku masyarakat (Ali et al., 2019).

Peningkatan pengetahuan bermanfaat untuk membentuk perilaku kesehatan masyarakat yang positif dalam menemukan pelayanan kesehatan dan pengobatan yang tepat (Anandari, Masfiah, \& Wijayanti, 2018). Hasil penelitian menunjukkan bahwa peningkatan pengetahuan masyarakat tentang penyebab TBC berhubungan dengan peningkatan deteksi dini TBC di masyarakat (Frost, Markham, \& Springer, 2018). Peningkatan pengetahuan tentang penyakit TBC meningkatkan motivasi untuk melakukan kunjungan ke pelayanan kesehatan (Afoakwa \& Taylor, 2018).

Kelurahan Mojosongo merupakan kelurahan yang berada di Kota Surakarta dengan jumlah rukun warga (RW) sebanyak 39 RW. Kelurahan Mojosongo mempunyai kader terlatih dan aktif 696 $(90,27 \%)$. Masalah kesehatan yang terjadi di Kelurahan Mojosongo adalah masih tingginya kejadian TBC, dengan kasus TBC sebanyak 15 orang. Kegiatan pengabdian masyarakat dilakukan dengan metode pemberian pendidikan kesehatan melalui pendekatan model information, motivation, and behavioral skills/IMB (Alegria-Flores et al., 2017). Kegiatan ini bertujuan untuk melakukan deteksi dini, meningkatkan pengetahuan, sikap, dan ketrampilan dalam upaya pencegahan penularan TBC.

masyarakat ini adalah "Apakah pendekatan model information, motivation, and behavioral skills dapat mendukung program stop TBC?". Pencarian literatur dengan metode PICO yaitu Population: community; Intervention: health education 
information, motivation, and behavioral skills model; Comparation: health education; Outcome: knowledge, motivation, dan behavioral skills. Evidence based practice yang dipilih adalah model Information, Motivation, and Behavioral Skills.

Sasaran dalam kegiatan pengabdian masyarakat ini adalah kelompok kunci berjumlah 43 peserta yang meliputi kader kesehatan, tokoh agama, tokoh masyarakat, dan kelompok berisiko (tinggal di lingkungan yang sanitasinya tidak adekuat, tinggal di daerah dengan kejadian TBC tinggi, kepadatan hunian tinggi). Kegiatan pengabdian masyarakat stop TBC melalui pendekatan model IMB ini dilaksanakan di Kelurahan Mojosongo RW XXVI pada tanggal 22 Juli-4 September 2019.

Tahapan atau prosedur yang dilakukan dalam kegiatan pengabdian kepada masyarakat meliputi tahap persiapan, pelaksanaan, dan evaluasi. Tahap persiapan dilakukan 22 Juli-3 Agustus 2019 meliputi pengecekan modul dan mengurus perijinan dari pemangku kepentingan. Tahap pelaksanaan pada tanggal 4 Agustus 2019 meliputi pemberian pendidikan kesehatan tentang penanganan dan pencegahan TBC, serta deteksi dini TBC di masyarakat. Pendidikan kesehatan diberikan oleh narasumber dengan media audiovisual dan modul dari Poltekkes Kemenkes Surakarta untuk meningkatkan pengetahuan; sedangkan cara deteksi dini oleh Penanggung Jawab Program TBC Puskesmas Sibela dan Kader Kesehatan Program TBC untuk meningkatkan ketrampilan. Kader TBC kemudian mempraktikan cara menggunakan masker dan etika batuk. Pada proses pelaksanaan juga dilakukan pendampingan kepada kelompok berisiko tinggi selama 4 minggu oleh kader kesehatan untuk meningkatkan sikap. Tahap evaluasi dilakukan pada tanggal 4 September 2019 dengan pengisian kuesioner terdiri atas evaluasi information, motivation, dan behavioral skills yang merupakan pengembangan kuesioner dari Yin et al. (2018).

Kuesioner tersebut terdiri atas evaluasi information, motivation, dan behavioral skills. Information meliputi konsep penyakit TBC, penyebab TBC, cara penularan infeksi penyakit TBC, dan cara pencegahan penyakit TBC (pemakaian masker bedah dan respirator, etika batuk, dan ventilasi alami). Motivation meliputi sikap terhadap penyakit TBC, sikap terhadap pencegahan penularan TBC (penggunaan masker, etika batuk, dan ventilasi alami). Behavioral skills meliputi kemampuan deteksi dini TBC, ketrampilan etika batuk, ketrampilan menggunakan masker, dan pelaksanaan ventilasi alami di rumah. 


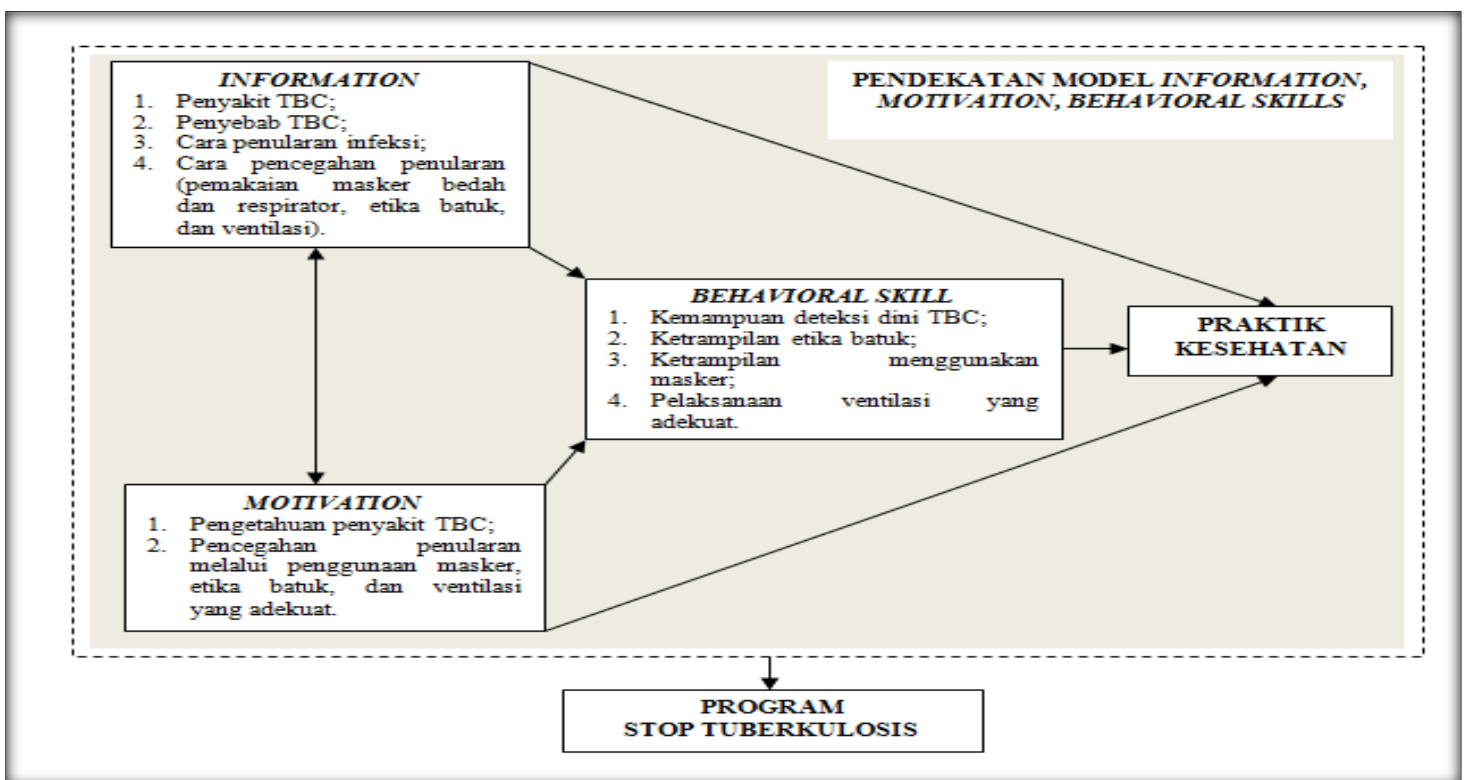

Gambar 1. Pendekatan Model Information, Motivation, and Behavioral Skills (IMB) dalam Program Stop Tuberkulosis

Sumber: Kanjee et al. (2012)

\section{HASIL DAN PEMBAHASAN}

Deteksi dini TBC dilakukan dengan melibatkan stakeholder yaitu Puskesmas Sibela dan kader kesehatan. Kegiatan deteksi dini ini dengan melakukan skrining melalui penyebaran kuesioner yang diisi oleh para peserta kegiatan pengabdian masyarakat. Hasil deteksi dini menunjukkan bahwa terdapat 2 orang $(4,7 \%)$ yang mengalami gejala utama TBC yaitu batuk berdahak 2 minggu atau lebih. Gejala tambahan yang paling sering dialami adalah penurunan berat badan oleh sebanyak 8 orang $(18,6 \%)$. Pada orang yang mengalami gejala utama TBC, maka dilakukan pemeriksaan dahak atau sputum dengan pot yang telah disediakan oleh petugas Puskesmas Sibela. Deskripsi tentang hasil skrining dijelaskan pada Tabel 1.

Hasil kegiatan pengabdian masyarakat ini sesuai dengan hasil telaah sistematik oleh Barss et al. (2020) bahwa pendidikan kesehatan pada kader dapat meningkatkan deteksi dini 28 kasus per 100 kasus yang teridentifikasi TBC. Hasil penelitian oleh Gebretnsae et al. (2020) merekomendasikan untuk meningkatkan praktik deteksi dini untuk menurunkan penularan TBC. Pemberdayaan masyarakat dengan melibatkan kader kesehatan dan tokoh masyarakat didukung oleh petugas kesehatan multidisiplin dapat meningkatkan deteksi dini dan keberhasilan program stop TBC (Pinto et al., 2018).

Hasil telaah sistematik menunjukkan deteksi dini TBC bermanfaat pada kesehatan masyarakat dan individu. Keuntungan bagi masyarakat adalah berkontribusi dalam pencegahan penularan TBC dan menyediakan data epidemiologi yang dijadikan dasar intervensi kesehatan. Keuntungan bagi individu adalah dapat memperoleh penanganan lebih dini, sehingga dapat mencegah komplikasi akibat TBC (Hermanns, Bhan, \& Viney, 2020). 
Tabel 1. Hasil Deteksi Dini Tuberkulosis di Kelurahan Mojosongo ( $n=43$ orang)

\begin{tabular}{|c|c|c|c|}
\hline \multirow[t]{2}{*}{ No } & \multirow[t]{2}{*}{ Pertanyaan } & \multicolumn{2}{|c|}{ Jawaban } \\
\hline & & $\begin{array}{c}\text { Ya } \\
\mathbf{n}(\%)\end{array}$ & $\begin{array}{l}\text { Tidak } \\
\text { n (\%) }\end{array}$ \\
\hline 1 & $\begin{array}{l}\text { Apakah } \text { Bapak/Ibu } \\
\text { mengalami batuk } 2 \\
\text { minggu atau lebih? }\end{array}$ & $\begin{array}{c}2 \\
(4,7 \%)\end{array}$ & $\begin{array}{c}41 \\
(95,3 \%)\end{array}$ \\
\hline 2 & $\begin{array}{lr}\text { Apakah } & \text { Bapak/Ibu } \\
\text { mengalami } & \text { batuk } \\
\text { disertai bercak darah? }\end{array}$ & $\begin{array}{c}1 \\
(2,3 \%)\end{array}$ & $\begin{array}{c}42 \\
(97,7 \%)\end{array}$ \\
\hline 3 & $\begin{array}{lr}\text { Apakah } & \text { Bapak/lbu } \\
\text { batuk } & \text { sering } \\
\text { berkeringat } & \text { dingin } \\
\text { terutama jika } & \text { malam } \\
\text { hari? } & \\
\end{array}$ & $\begin{array}{c}0 \\
(0 \%)\end{array}$ & $\begin{array}{c}43 \\
(100 \%)\end{array}$ \\
\hline 4 & $\begin{array}{l}\text { Apakah Bapak/Ibu } \\
\text { terasa lemah ketika } \\
\text { beraktivitas? }\end{array}$ & $\begin{array}{c}3 \\
(7 \%)\end{array}$ & $\begin{array}{c}40 \\
(93 \%)\end{array}$ \\
\hline 5 & $\begin{array}{l}\text { Apakah } \text { Bapak/Ibu } \\
\text { mengalami penurunan } \\
\text { berat badan? }\end{array}$ & $\begin{array}{c}8 \\
(18,6 \%)\end{array}$ & $\begin{array}{c}35 \\
(81,4 \%)\end{array}$ \\
\hline 6 & $\begin{array}{lr}\text { Apakah } & \text { Bapak/Ibu } \\
\text { nafsu } & \text { makan } \\
\text { berkurang? } & \end{array}$ & $\begin{array}{c}5 \\
(11,6 \%)\end{array}$ & $\begin{array}{c}38 \\
(88,4 \%)\end{array}$ \\
\hline 7 & $\begin{array}{l}\text { Apakah Bapak/Ibu } \\
\text { mengalami } \\
\text { panas/demam berulang- } \\
\text { ulang? }\end{array}$ & $\begin{array}{c}1 \\
(2,3 \%)\end{array}$ & $\begin{array}{c}42 \\
(97,7 \%)\end{array}$ \\
\hline 8 & $\begin{array}{lr}\text { Apakah } & \text { Bapak/Ibu } \\
\text { mengalami } & \text { sesak } \\
\text { nafas? } & \\
\end{array}$ & $2(4,7 \%)$ & $\begin{array}{c}41 \\
(95,3 \%)\end{array}$ \\
\hline
\end{tabular}

Tabel 2. menunjukkan hasil evaluasi tentang information atau pengetahuan. Pengetahuan masyarakat tentang gejala penyakit TBC mayoritas peserta menjawab benar dengan rata-rata 32 orang $(74,4 \%)$. Pengetahuan masyarakat tentang penularan penyakit TBC mayoritas menjawab benar dengan rata-rata 32 orang $(74,4 \%)$, pengetahuan tentang penularan penyakit TBC terendah adalah tentang penularan TBC melalui darah sebanyak 22 orang (51,2\%). Pengetahuan tentang penggunaan masker untuk pencegahan TBC mayoritas menjawab benar sebanyak $41(95,3 \%)$ orang. Pengetahuan tentang etika batuk untuk pencegahan penyakit TBC mayoritas menjawab benar sebanyak $41(95,3 \%)$ orang. Pengetahuan tentang ventilasi mekanik untuk pencegahan penyakit TBC mayoritas menjawab benar sebanyak $37(86 \%)$ orang. Pengetahuan tentang cara deteksi pasien TBC mayoritas menjawab benar sebanyak 41 (95,3\%).

Penelitian yang dilakukan oleh Bisallah et al. (2018) menyatakan bahwa pendidikan kesehatan dengan menggunakan modul Knowledge, Attitude, and Practice (KAP) efektif meningkatkan pengetahuan, nilai, dan praktik pasien TBC koinfeksi HIV. Peningkatan pengetahuan masyarakat dapat menurunkan stigma tentang penyakit TBC. Hasil penelitian menunjukkan bahwa stigma yang negatif berhubungan dengan pengetahuan masyarakat yang rendah tentang pencegahan TBC. Stigma merupakan fenomena yang berpengaruh terhadap keberhasilan program kesehatan di institusi pemerintah, nilai individu, dan masyarakat (Datiko, Jerene, \& Suarez, 2020).

Stigma menyebabkan masalah seperti isolasi, penolakan, dan perilaku kesehatan yang salah. Stigma di masyarakat berpengaruh terhadap perilaku pencarian pelayanan kesehatan. Stigma yang berkembang di masyarakat terhadap penyakit TBC antara lain pengetahuan bahwa penyakit TBC akan menular melalui makanan dan minuman, masyarakat takut berinteraksi dekat dengan orang yang terkena TBC, serta TBC merupakan penyakit keturunan. Intervensi untuk mengidentifikasi karakteristik dan penurunan stigma di masyarakat merupakan tantangan bagi keberhasilan program stop TBC (Yin et al., 2018).

Tabel 2. Hasil Kuesioner Information (Pengetahuan) di Kelurahan Mojosongo $(n=43$ orang)

\begin{tabular}{|c|c|c|c|}
\hline \multirow[t]{2}{*}{ No } & \multirow[t]{2}{*}{ Pernyataan } & \multicolumn{2}{|c|}{ Jawaban } \\
\hline & & $\begin{array}{l}\text { Benar } \\
\text { n }(\%)\end{array}$ & $\begin{array}{l}\text { Salah } \\
\text { n }(\%) \\
\end{array}$ \\
\hline $\mathbf{A}$ & Gejala Penyakit TBC & & \\
\hline 1 & $\begin{array}{lll}\begin{array}{l}\text { Pandangan } \\
\text { merupakan } \\
\text { (Salah) }\end{array} & \text { gejala } & \text { kabur } \\
\text { TBC. }\end{array}$ & $\begin{array}{c}28 \\
(65,1 \%)\end{array}$ & $\begin{array}{c}15 \\
(34,9 \%)\end{array}$ \\
\hline 2 & $\begin{array}{lll}\text { Batuk selama } & 2 \text { minggu } \\
\text { atau } & \text { lebih merupakan } \\
\text { gejala } & \text { TBC. (Benar) }\end{array}$ & $\begin{array}{c}32 \\
(74,4 \%)\end{array}$ & $\begin{array}{c}11 \\
(25,6 \%)\end{array}$ \\
\hline 3 & $\begin{array}{l}\text { Batuk berdarah merupakan } \\
\text { gejala TBC. (Benar) }\end{array}$ & $\begin{array}{c}38 \\
(88,4 \%)\end{array}$ & $\begin{array}{c}5 \\
(11,6 \%)\end{array}$ \\
\hline
\end{tabular}

JPPM ISSN: 2549 - 8347 (Online) 
Rita Benya Adriani, Dyah Dwi Astuti, Tri Widyastuti Handayani

Stop Tuberkulosis Melalui Pendekatan Model Information Motivation and Behavioral Skills (IMB)

\begin{tabular}{|c|c|c|c|}
\hline \multirow[t]{2}{*}{ No } & \multirow[t]{2}{*}{ Pernyataan } & \multicolumn{2}{|c|}{ Jawaban } \\
\hline & & $\begin{array}{l}\text { Benar } \\
\text { n }(\%)\end{array}$ & $\begin{array}{l}\text { Salah } \\
\text { n }(\%)\end{array}$ \\
\hline 4 & $\begin{array}{l}\text { Demam merupakan gejala } \\
\text { TBC. (Benar) }\end{array}$ & $\begin{array}{c}28 \\
(65,1 \%) \\
\end{array}$ & $\begin{array}{c}15 \\
(34,9 \%) \\
\end{array}$ \\
\hline 5 & \begin{tabular}{lr} 
Ingatan & \multicolumn{2}{r}{ berkurang } \\
merupakan & gejala TBC. \\
(Salah) &
\end{tabular} & $\begin{array}{c}33 \\
(76,7 \%)\end{array}$ & $\begin{array}{c}10 \\
(23,3 \%)\end{array}$ \\
\hline 6 & $\begin{array}{l}\text { Keringat malam hari tanpa } \\
\text { aktivitas merupakan gejala } \\
\text { TBC. (Benar) }\end{array}$ & $\begin{array}{c}28 \\
(65,1 \%)\end{array}$ & $\begin{array}{c}15 \\
(34,9 \%)\end{array}$ \\
\hline 7 & $\begin{array}{lll}\begin{array}{l}\text { Penurunan } \\
\text { merupakan }\end{array} & \text { berat } & \text { gejala } \\
\text { (Benar) } & \text { TBC. } \\
\end{array}$ & $\begin{array}{c}34 \\
(79,1 \%)\end{array}$ & $\begin{array}{c}9 \\
(20,9 \%)\end{array}$ \\
\hline & Rata-Rata & $\begin{array}{c}32 \\
(74,4 \%) \\
\end{array}$ & $\begin{array}{c}11 \\
(25,6 \%) \\
\end{array}$ \\
\hline $\mathbf{B}$ & Penularan Penyakit TBC & & \\
\hline 1 & $\begin{array}{l}\text { Penularan TBC melalui } \\
\text { udara. (Benar) }\end{array}$ & $\begin{array}{c}39 \\
(90,7 \%)\end{array}$ & $\begin{array}{c}4 \\
(9,3 \%)\end{array}$ \\
\hline 2 & $\begin{array}{l}\text { Penularan TBC melalui } \\
\text { darah. (Salah) }\end{array}$ & $\begin{array}{c}22 \\
(51,2 \%)\end{array}$ & $\begin{array}{c}21 \\
(48,8 \%) \\
\end{array}$ \\
\hline 3 & $\begin{array}{l}\text { Seseorang dengan TBC } \\
\text { dapat menularkan penyakit } \\
\text { ke orang lain melalui } \\
\text { batuk, bersin, dan bicara } \\
\text { tanpa memakai masker. } \\
\text { (Benar) }\end{array}$ & $\begin{array}{c}42 \\
(97,7 \%)\end{array}$ & $\begin{array}{c}1 \\
(2,3 \%)\end{array}$ \\
\hline 4 & $\begin{array}{l}\text { Seseorang dengan } \mathrm{TBC} \\
\text { dapat menularkan penyakit } \\
\text { ke orang lain melalui } \\
\text { makan. (Salah) }\end{array}$ & $\begin{array}{c}23 \\
(53,5 \%)\end{array}$ & $\begin{array}{c}20 \\
(46,5 \%)\end{array}$ \\
\hline 5 & $\begin{array}{l}\text { Seseorang dengan TBC } \\
\text { dapat menularkan penyakit } \\
\text { ke orang lain melalui } \\
\text { pakaian yang dipakai. } \\
\text { (Salah) }\end{array}$ & $\begin{array}{c}30 \\
(69,8 \%)\end{array}$ & $\begin{array}{c}13 \\
(30,2 \%)\end{array}$ \\
\hline 6 & $\begin{array}{l}\text { Pengobatan TBC yang } \\
\text { teratur dapat menurunkan } \\
\text { risiko penularan ke orang } \\
\text { lain. (Benar) }\end{array}$ & $\begin{array}{c}33 \\
(76,7 \%)\end{array}$ & $\begin{array}{c}10 \\
(23,3 \%)\end{array}$ \\
\hline & Rata-Rata & $\begin{array}{c}32 \\
(74,4 \%) \\
\end{array}$ & $\begin{array}{c}11 \\
(25,6 \%) \\
\end{array}$ \\
\hline $\mathbf{C}$ & Penggunaan Masker & & \\
\hline 1 & $\begin{array}{lr}\text { Menggunakan } & \text { masker } \\
\text { dapat } & \text { mengurangi } \\
\text { terhirupnya } & \text { kuman } \\
\text { penyebab TBC. } & \text { (Benar) } \\
\end{array}$ & $\begin{array}{c}42 \\
(97,7 \%)\end{array}$ & $\begin{array}{c}1 \\
(2,3 \%)\end{array}$ \\
\hline 2 & $\begin{array}{lr}\text { Menggunakan } & \text { masker } \\
\text { dapat mengurangi } & \text { jumlah } \\
\text { kuman penyebab } & \text { TBC } \\
\text { menyebar ke } & \text { udara. } \\
\text { (Benar) } & \\
\end{array}$ & $\begin{array}{c}39 \\
(90,7 \%)\end{array}$ & $\begin{array}{c}4 \\
(9,3 \%)\end{array}$ \\
\hline 3 & \begin{tabular}{l}
\multicolumn{3}{l}{ Saat menggunakan masker } \\
perlu mengecek area \\
hidung dan mulut yang \\
ditutupi. (Benar)
\end{tabular} & $\begin{array}{c}41 \\
(95,3 \%)\end{array}$ & $\begin{array}{c}2 \\
(4,7 \%)\end{array}$ \\
\hline & Rata-Rata & $\begin{array}{c}41 \\
(95,3 \%) \\
\end{array}$ & $\begin{array}{c}2 \\
(4,7 \%)\end{array}$ \\
\hline $\mathbf{D}$ & Etika Batuk & & \\
\hline 1 & $\begin{array}{l}\text { Seseorang yang terkena } \\
\text { TBC bebas bersin atau } \\
\text { batuk di tempat terbuka. } \\
\text { (Salah) }\end{array}$ & $\begin{array}{c}33 \\
(76,7 \%)\end{array}$ & $\begin{array}{c}10 \\
(23,3 \%)\end{array}$ \\
\hline 2 & \begin{tabular}{lrr} 
Selama & \multicolumn{2}{c}{ berkomunikasi } \\
dengan & seseorang yang \\
terkena & TBC yang sudah
\end{tabular} & $\begin{array}{c}33 \\
(76,7 \%)\end{array}$ & $\begin{array}{c}10 \\
(23,3 \%)\end{array}$ \\
\hline
\end{tabular}

\begin{tabular}{|c|c|c|c|}
\hline \multirow[t]{2}{*}{ No } & \multirow[t]{2}{*}{ Pernyataan } & \multicolumn{2}{|c|}{ Jawaban } \\
\hline & & $\begin{array}{l}\text { Benar } \\
\text { n }(\%)\end{array}$ & $\begin{array}{l}\text { Salah } \\
\text { n (\%) }\end{array}$ \\
\hline & $\begin{array}{l}\text { menggunakan masker, kita } \\
\text { tidak perlu menggunakan } \\
\text { masker. (Salah) }\end{array}$ & & \\
\hline 3 & $\begin{array}{l}\text { Seseorang yang diduga } \\
\text { TBC, maka kita tidak perlu } \\
\text { menggunakan masker saat } \\
\text { berkomunikasi. (Salah) }\end{array}$ & $\begin{array}{c}33 \\
(76,7 \%)\end{array}$ & $\begin{array}{c}10 \\
(23,3 \%)\end{array}$ \\
\hline & Rata-Rata & $\begin{array}{c}33 \\
(76,7 \%) \\
\end{array}$ & $\begin{array}{c}10 \\
(23,3 \%)\end{array}$ \\
\hline $\mathbf{E}$ & Ventilasi Alami & & \\
\hline 1 & $\begin{array}{l}\text { Membuka jendela dapat } \\
\text { mencegah } \\
\text { bakteri penyebab } \\
\text { (Benar) }\end{array}$ & $\begin{array}{c}32 \\
(74,4 \%)\end{array}$ & $\begin{array}{c}11 \\
(25,6 \%)\end{array}$ \\
\hline 2 & $\begin{array}{l}\text { Lingkungan yang sehat } \\
\text { dapat mencegah terjadinya } \\
\text { penyakit TBC. (Benar) }\end{array}$ & $\begin{array}{c}42 \\
(97,7 \%)\end{array}$ & $\begin{array}{c}1 \\
(2,3 \%)\end{array}$ \\
\hline & Rata-Rata & $37(86 \%)$ & $6(13 \%)$ \\
\hline $\mathbf{F}$ & Deteksi Awal Pasien TBC & & \\
\hline 1 & $\begin{array}{lr}\text { Setiap orang yang } & \text { batuk } \\
\text { selama } 2 \text { minggu atau lebih } \\
\text { dianjurkan } & \text { untuk } \\
\text { memeriksakan } & \text { dahak. } \\
\text { (Benar) } & \\
\end{array}$ & $\begin{array}{c}41 \\
(95,3 \%)\end{array}$ & $\begin{array}{c}2 \\
(4,7 \%)\end{array}$ \\
\hline 2 & $\begin{array}{l}\text { Seseorang yang terduga } \\
\text { TBC perlu diperiksa dahak } \\
\text { yang diambil pada pagi } \\
\text { hari dan sewaktu. (Benar) }\end{array}$ & $\begin{array}{c}41 \\
(95,3 \%)\end{array}$ & $\begin{array}{c}2 \\
(4,7 \%)\end{array}$ \\
\hline & Rata-Rata & $\begin{array}{c}41 \\
(95,3 \%)\end{array}$ & $\begin{array}{c}2 \\
(4,7 \%)\end{array}$ \\
\hline
\end{tabular}

Tabel 3. mendeskripsikan tentang evaluasi motivation atau sikap terhadap penyakit TBC. Pada pernyataan nomor 1 dan 2 menunjukkan bahwa mayoritas masyarakat mempunyai sikap peduli jika terkena penyakit TBC. Pada pernyataan nomor 3, 4, dan 5 menunjukkan mayoritas masyarakat mempunyai kepedulian terhadap lingkungan sekitar tentang upaya pencegahan TBC. Pada pernyataan nomor $6,7,8$, dan 9 menunjukkan mayoritas masyarakat mempunyai sikap yang positif terhadap penggunaan masker, etika batuk, dan ventilasi alami untuk pencegahan penularan TBC. Pada pernyataan nomor nomor 10 menunjukkan bahwa mayoritas keluarga dan lingkungan kerja mendukung upaya pencegahan penulran penyakit TBC.

Motivasi dalam penerapan model IMB meliputi motivasi untuk meningkatkan pengetahuan penyakit TBC, pencegahan penularan melalui penggunaan 
Rita Benya Adriani, Dyah Dwi Astuti, Tri Widyastuti Handayani

Stop Tuberkulosis Melalui Pendekatan Model Information Motivation and Behavioral Skills (IMB)

masker, etika batuk, dan ventilasi yang adekuat (Floyd et al., 2018). Hasil penelitian menunjukkan bahwa motivasi dapat meningkatkan perilaku ketrampilan seperti ketrampilan etika batuk, ketrampilan menggunakan masker, dan pelaksanaan ventilasi yang adekuat (Kanjee et al., 2012). Peningkatan motivasi dan sikap dalam pencegahan penularan TBC didukung oleh pengetahuan dan dukungan sosial yang adekuat (AlegriaFlores et al., 2017).

Tabel 3. Hasil Kuesioner Motivation (Sikap) di Kelurahan Mojosongo $(n=43$ orang)

\begin{tabular}{|c|c|c|c|}
\hline \multirow[t]{2}{*}{ No } & \multirow[t]{2}{*}{ Pernyataan } & Setuju & $\begin{array}{c}\text { Tidak } \\
\text { Setuju } \\
\end{array}$ \\
\hline & & n (\%) & n (\%) \\
\hline 1 & $\begin{array}{lr}\text { Ketika saya } & \text { terkena } \\
\text { TBC, maka hal tersebut } \\
\text { tidak } & \text { terlalu } \\
\text { mengganggu } & \text { kehidupan } \\
\text { saya. }\end{array}$ & $\begin{array}{c}8 \\
(18,6 \%)\end{array}$ & $\begin{array}{c}35 \\
(81,4 \%)\end{array}$ \\
\hline 2 & $\begin{array}{l}\text { Ketika ada anggota } \\
\text { keluarga saya yang } \\
\text { terkena TBC, maka hal } \\
\text { tersebut tidak terlalu } \\
\text { mengganggu kehidupan } \\
\text { saya. }\end{array}$ & $\begin{array}{c}11 \\
(25,6 \%)\end{array}$ & $\begin{array}{c}32 \\
(74,4 \%)\end{array}$ \\
\hline 3 & $\begin{array}{l}\text { Saya merasa perlu untuk } \\
\text { menanyakan seseorang } \\
\text { yang berisiko terkena } \\
\text { penyakit TBC apakah } \\
\text { mengalami batuk atau } \\
\text { tidak. }\end{array}$ & $\begin{array}{c}41 \\
(95,3 \%)\end{array}$ & $\begin{array}{c}2 \\
(4,7 \%)\end{array}$ \\
\hline 4 & $\begin{array}{l}\text { Saya merasa perlu untuk } \\
\text { meminimalkan } \\
\text { penyebaran penyakit } \\
\text { TBC di masyarakat. }\end{array}$ & $\begin{array}{c}42 \\
(97,7 \%)\end{array}$ & $\begin{array}{c}1 \\
(2,3 \%)\end{array}$ \\
\hline 5 & \begin{tabular}{lr}
\multicolumn{2}{l}{ Saya merasa perlu untuk } \\
mengetahui & status \\
apakah saya & terkena \\
TBC atau tidak. & \\
\end{tabular} & $\begin{array}{c}42 \\
(97,7 \%)\end{array}$ & $\begin{array}{c}1 \\
(2,3 \%)\end{array}$ \\
\hline 6 & $\begin{array}{ll}\text { Saya merasa tidak } \\
\text { nyaman } \\
\text { masker. }\end{array}$ & $\begin{array}{c}4 \\
(9,3 \%)\end{array}$ & $\begin{array}{c}39 \\
(90,7 \%)\end{array}$ \\
\hline 7 & $\begin{array}{l}\text { Saya merasa terganggu } \\
\text { penampilannya ketika } \\
\text { memakai masker. }\end{array}$ & $\begin{array}{c}9 \\
(20,9 \%)\end{array}$ & $\begin{array}{c}34 \\
(79,1 \%)\end{array}$ \\
\hline 8 & $\begin{array}{lr}\text { Saya merasa enggan } \\
\text { untuk } & \text { meminta } \\
\text { seseorang } & \text { untuk } \\
\text { menutup mulut dan } \\
\text { hidung dengan tisue } \\
\text { ketika batuk atau bersin. }\end{array}$ & $\begin{array}{c}11 \\
(25,6 \%)\end{array}$ & $\begin{array}{c}32 \\
(74,4 \%)\end{array}$ \\
\hline 9 & $\begin{array}{l}\text { Saya menyukai menutup } \\
\text { jendela rumah pada } \\
\text { siang hari. }\end{array}$ & $\begin{array}{c}5 \\
(11,6 \%)\end{array}$ & $\begin{array}{c}38 \\
(88,4 \%)\end{array}$ \\
\hline
\end{tabular}

\begin{tabular}{|c|c|c|c|}
\hline \multirow[t]{2}{*}{ No } & Pernyataan & Setuju & $\begin{array}{l}\text { Tidak } \\
\text { Setuju }\end{array}$ \\
\hline & & n (\%) & n (\%) \\
\hline 10 & $\begin{array}{l}\text { Keluarga dan lingkungan } \\
\text { kerja saya mendukung } \\
\text { saya dalam upaya } \\
\text { pencegahan penularan } \\
\text { penyakit TBC. }\end{array}$ & $\begin{array}{c}40 \\
(93 \%)\end{array}$ & $\begin{array}{c}3 \\
(7 \%)\end{array}$ \\
\hline
\end{tabular}

Tabel 4. mendeskripsikan tentang evaluasi behavioral skill atau kemampuan terhadap pencegahan penularan penyakit TBC. Pada pernyataan nomor 1 dan 2 menunjukkan bahwa mayoritas masyarakat melakukan etika batuk. Pada pernyataan nomor 3, 4, dan 5 menunjukkan bahwa mayoritas masyarakat memakai masker untuk pencegahan penularan penyakit TBC. Pada pernyataan nomor 6 dan 7 menunjukkan bahwa mayoritas masyarakat melakukan ventilasi alami untuk pencegahan penularan penyakit TBC.

Hasil kegiatan pengabdian masyarakat ini sesuai dengan penelitian Anggraini, Soedarsono, dan Hidayati (2020). Penelitian dengan jenis kuasi eksperimen yang dilakukan pada 72 pasien TBC. Pendidikan kesehatan dilakukan dengan pendekatan psikoedukasi. Hasil penelitian menunjukkan terjadi peningkatan perilaku pencegahan penularan TBC. Hasil penelitian lainnya yang dilakukan di Korea menunjukkan bahwa peningkatan ketrampilan hygiene masyarakat yang meliputi mencuci tangan dan etika batuk akan menurunkan kejadian penularan TBC dan menurunkan mortalitas di masyarakat. Penelitian tersebut merekomendasikan untuk melakukan kegiatan promosi kesehatan berbasis masyarakat untuk pencegahan penularan TBC (Han, 2018).

Tabel 4. Hasil Kuesioner Behavioral Skill (Kemampuan) di Kelurahan Mojosongo ( $n=43$ orang)

\begin{tabular}{ccccc}
\hline No & Pernyataan & Dilakukan & $\begin{array}{c}\text { Tidak } \\
\text { Dilakukan }\end{array}$ \\
\cline { 3 - 4 } & & $\mathbf{n}(\%)$ & $\mathbf{n}(\%)$ \\
\hline 1 & $\begin{array}{l}\text { Bertanya } \\
\text { masyarakat }\end{array}$ & $\begin{array}{l}\text { kepada } \\
\text { apakah }\end{array}$ & $\begin{array}{c}40 \\
(93 \%)\end{array}$ & $\begin{array}{c}3 \\
(7 \%)\end{array}$ \\
\hline
\end{tabular}


Rita Benya Adriani, Dyah Dwi Astuti, Tri Widyastuti Handayani

Stop Tuberkulosis Melalui Pendekatan Model Information Motivation and Behavioral Skills (IMB)

\begin{tabular}{|c|c|c|c|}
\hline No & Pernyataan & Dilakukan & $\begin{array}{c}\text { Tidak } \\
\text { Dilakukan }\end{array}$ \\
\hline & $\begin{array}{l}\text { mengalami batuk atau } \\
\text { tidak, jika mengalami } \\
\text { batuk sudah berapa } \\
\text { lama. }\end{array}$ & & \\
\hline 2 & $\begin{array}{l}\text { Menutup mulut dan } \\
\text { hidung ketika batuk } \\
\text { atau bersin dengan } \\
\text { tisue atau bagian } \\
\text { dalam lengan tangan. }\end{array}$ & $\begin{array}{c}34 \\
(79,1 \%)\end{array}$ & $\begin{array}{c}9 \\
(20,9 \%)\end{array}$ \\
\hline 3 & $\begin{array}{l}\text { Mempunyai masker } \\
\text { sendiri. }\end{array}$ & $\begin{array}{c}41 \\
(95,3 \%)\end{array}$ & $\begin{array}{c}2 \\
(4,7 \%)\end{array}$ \\
\hline 4 & $\begin{array}{l}\text { Merasa nyaman ketika } \\
\text { memakai masker. }\end{array}$ & $\begin{array}{c}40 \\
(93 \%)\end{array}$ & $\begin{array}{c}3 \\
(7 \%)\end{array}$ \\
\hline 5 & $\begin{array}{l}\text { Berinteraksi dengan } \\
\text { dengan seseorang yang } \\
\text { terkena TBC dengan } \\
\text { menggunakan masker. }\end{array}$ & $\begin{array}{c}39 \\
(90,7 \%)\end{array}$ & $\begin{array}{c}4 \\
(9,3 \%)\end{array}$ \\
\hline 6 & $\begin{array}{l}\text { Membuka jendela di } \\
\text { rumah. }\end{array}$ & $\begin{array}{c}41 \\
(95,3 \%)\end{array}$ & $\begin{array}{c}2 \\
(4,7 \%)\end{array}$ \\
\hline 7 & 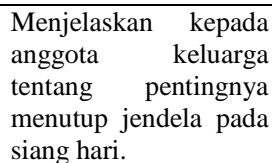 & $\begin{array}{c}20 \\
(46,5 \%)\end{array}$ & $\begin{array}{c}23 \\
(53,5 \%)\end{array}$ \\
\hline
\end{tabular}

Kegiatan pengabdian masyarakat dengan pendekatan model IMB mendeskripsikan tindakan yang berhubungan dengan perubahan perilaku dengan melakukan pengembangan, monitor, dan evaluasi intervensi pendidikan kesehatan tentang pencegahan penularan TBC. Hal ini sesuai dengan penelitian oleh Pinto et al. (2018) bahwa pelaksanaan program pendidikan kesehatan bermanfaat dalam meningkatkan kesadaran masyarakat dan memperkuat koordinasi antara masyarakat dengan petugas kesehatan terutama di pelayanan kesehatan primer seperti puskesmas. Peningkatan koordinasi tersebut berdampak pada keberhasilan program kesehatan seperti stop TBC, serta peningkatan kemampuan masyarakat dalam mengambil keputusan untuk melakukan pengobatan yang tepat. Pengetahuan masyarakat tentang penyakit TBC akan berpengaruh terhadap respons perilaku masyarakat (Ali et al., 2019). $\begin{array}{clr}\text { SIMPULAN } & \\ \text { Hasil } & \text { pelaksanaan } & \text { kegiatan } \\ \text { pengabdian } & \text { masyarakat } & \text { melalui }\end{array}$ pendekatan Information, Motivation, and Behavioral Skill dapat meningkatkan pengetahuan, sikap, dan ketrampilan yang positif dalam upaya pencegahan penularan TBC. Rekomendasi dari kegiatan pengabdian masyarakat ini adalah untuk melaksanakan kegiatan pengabdian masyarakat secara berkelanjutan dengan melibatkan stakeholder seperti puskesmas, kader kesehatan, dan tokoh masyarakat dalam rangka mendukung program pemerintah di bidang kesehatan yaitu stop TBC.

\section{UCAPAN TERIMA KASIH}

Ucapan terima kasih kepada Poltekkes Kemenkes Surakarta yang telah memberi dukungan finansial kegiatan pengabdian masyarakat ini.

\section{DAFTAR PUSTAKA}

Afoakwa, E., \& Taylor, J. (2018). Knowledge of tuberculosis and factors responsible for low case detection in the Amansie Central District, Ghana. South Sudan Medical Journal, 11(1), 8-12.

Alegria-Flores, K., Weiner, B. J., Wiesen, C. A., Lich, K. L. H., Van Rie, A., Paul, J. E., \& Tovar, M. A. (2017). Innovative approach to the design and evaluation of treatment adherence interventions for drug-resistant TB. The International Journal of Tuberculosis and Lung Disease, 21(11), 1160-1166. https://doi.org/10.5588/ijtld.17.0296.

Ali, S. M., Anjum, N., Ishaq, M., Naureen, F., Noor, A., Rashid, A., Abbas, S. M., Viney, K. (2019). Community knowledge about tuberculosis and perception about tuberculosisassociated stigma in Pakistan. Societies, $\quad 9(1), \quad 9$. 
https://doi.org/10.3390/soc9010009.

Anandari, D., Masfiah, S., \& Wijayanti, S. P. (2018). Factors associated with health seeking behavior among tuberculosis suspects in rural area. International Journal of Public Health and Clinical Sciences, 5(3), 209-217.

Anggraini, A. D., Soedarsono, \& Hidayati, L. (2020). The effect of psychoeducation based audiovisual program on behavior adherence for preventing tuberculosis transmission, International Journal of Nursing and Health Services, 3(3), 351-357. https://doi.org/10.35654/ijnhs.v3i3.21 7

Barss, L., Moayedi-Nia, S., Campbell, J. R., Oxlade, O., \& Menzies, D. (2020). Interventions to reduce losses in the cascade of care for latent tuberculosis: A systematic review and meta-analysis. The International Journal of Tuberculosis and Lung Disease, 24(1), 100-109. https://doi.org/10.5588/ijtld.19.0185

Bisallah, C. I., Rampal, L., Lye, M. S., Sidik, S. M., Ibrahim, N., Iliyasu, Z., \& Onyilo, M. O. (2018). Effectiveness of health education intervention in improving knowledge, attitude, and practices regarding Tuberculosis among HIV patients in General Hospital Minna, Nigeria - A randomized control trial. PLOS ONE, 13(2): e0192276, 1-14. https://doi.org/10.1371/journal.pone.0 192276.

Datiko, D. G., Jerene, D., \& Suarez, P. (2020). Stigma matters in ending tuberculosis: Nationwide survey of stigma in Ethiopia. BMC Public Health, 20(1), 190. https://doi.org/10.1186/s12889-0197915-6.

Dinas Kesehatan Provinsi Jawa Tengah.
(2019). Buku saku Kesehatan tahun 2019. Retrieved from http://www.dinkesjatengprov.go.id.

Floyd, K., Glaziou, P., Houben, R. M. G. J., Sumner, T., White, R. G., \& Raviglione, M. (2018). Global tuberculosis targets and milestones set for 2016-2035: Definition and rationale. International Journal of Tuberculosis and Lung Disease, 22(7), 723-730. https://doi.org/10.5588/ijtld.17.0835

Frost, E. L., Markham, C., \& Springer, A. (2018). Refugee health education: Evaluating a community-based approach to empowering refugee women in Houston, Texas. Advances in Social Work, 18(3), 949-964. https://doi.org/10.18060/21622.

Gebretnsae, H., Ayele, B. G., Hadgu, T., Haregot, E., Gebremedhin, A., Michael, E., Abraha, M. Datiko, D.G., \& Jerene, D. (2020). Implementation status of household contact tuberculosis screening by health extension workers: Assessment findings from programme implementation in Tigray region, northern Ethiopia. BMC Health Services Research, 20(1), 72. https://doi.org/10.1186/s12913-0204928-x.

Han, M. A. (2018). Hand hygiene and tuberculosis risk in Korea: An ecological association. Asia Pacific Journal of Public Health, 30(1), 6774.

https://doi.org/10.1177/10105395177 51746.

Hermanns, S., Bhan, A., \& Viney, K. (2020). Ethics and benefits of systematic screening for active tuberculosis. The International Journal of Tuberculosis and Lung Disease, 24(s1), 44-47. https://doi.org/10.5588/ijtld.17.0888. 
Kanjee, Z., Amico, K. R., Li, F., Mbolekwa, K., Moll, A. P., \& Friedland, G. H. (2012). Tuberculosis infection control in a high drugresistance setting in rural South Africa: Information, motivation, and behavioral skills. Journal of Infection and Public Health, 5(1), 67-81. https://doi.org/10.1016/j.jiph.2011.10 .008 .

Okeyo, I. L. A., \& Dowse, R. (2018). An illustrated booklet for reinforcing community health worker knowledge of tuberculosis and facilitating patient counselling. African Journal of Primary Health Care and Family Medicine, $\quad 10(1), \quad 1-7$. https://doi.org/10.4102/phcfm.v10i1. 1687.

Pinto, E. S. G., Queiroz, R. F. de, Carreiro, G. S. P., Morais, L. J., Medeiros, E. R. de, \& Villa, T. C. S. (2018). Coordination of health care with the community in the clinical management of tuberculosis. Revista Brasileira de Enfermagem, 71(3), 1122-1127. https://doi.org/10.1590/0034-71672017-0255

Watermeyer, J., \& Penn, C. (2019). Community perspectives on tuberculosis care in rural South Africa. Health and Social Care in the Community, 27(1), 182-190. https://doi.org/10.1111/hsc.12637

Yin, X., Yan, S., Tong, Y., Peng, X., Yang, T., Lu, Z., \& Gong, Y. (2018). Status of tuberculosis-related stigma and associated factors: A cross-sectional study in central China. Tropical Medicine and International Health, 23(2),

https://doi.org/10.1111/tmi.13017. 